\title{
Pengukuran Kinerja RSUD Dr. Saiful Anwar Melalui Metode Balanced Scorecard
}

\author{
${ }^{1}$ Erni Mitrawati, ${ }^{2}$ Edi Subiyantoro, ${ }^{3}$ Harmono \\ ${ }^{1,2,3}$ Magister Manajemen, Manajemen Keuangan Daerah, Fakultas Pascasarjana \\ Universitas Merdeka Malang, Indonesia
}

\begin{abstract}
The purpose of research to find out the performance measurement of RSUD Dr. Saiful Anwar through Balanced Scorecard method. The research method used in this research using mixed methods approach. The result of research shows that the measurement of public performance based on Balanced Scorecard method of RSUD Dr.Saiful Anwar Malang 2014 - 2016 is divided into 4 approaches: customer approach, financial approach, approach with internal business process and overall learning \& growth are included in good performance. The performance of hospitals Dr.Saiful Anwar Malang in the perspective of customers included in the category very well with the value reached 83.28, Performance RSUD Dr.Saiful Anwar Malang in the financial perspective included in the category good, Performance RSUD Dr.Saiful Anwar Malang in the perspective of internal business processes including in good category, and the performance of RSUD Dr.Saiful Anwar Malang in perspective of Learning \& Growth included in good category, so it can be said that RSUD Dr.Saiful Anwar Malang able to increase employee capability and employee commitment.
\end{abstract}

Keywords: Balanced Scorecard, Performance Measurement

\section{Abstrak}

Tujuan penelitian untuk mengetahui pengukuran kinerja RSUD Dr. Saiful Anwar melalui metode Balanced Scorecard. Metode penelitian yang digunakan dalam penelitian ini menggunakan pendekatan metode campuran. Hasil penelitian menunjukkan bahwa pengukuran kinerja publik berdasarkan metode Balanced Scorecard RSUD Dr.Saiful Anwar Malang 2014 - 2016 terbagi menjadi 4 pendekatan: pendekatan pelanggan, pendekatan keuangan, pendekatan dengan proses bisnis internal dan keseluruhan pembelajaran \& pertumbuhan termasuk dalam kinerja yang baik. Kinerja rumah sakit Dr.Saiful Anwar Malang dalam perspektif pelanggan termasuk dalam kategori sangat baik dengan nilai mencapai 83,28, Kinerja RSUD Dr.Saiful Anwar Malang dalam perspektif keuangan termasuk dalam kategori baik, Kinerja RSUD Dr.Saiful Anwar Malang dalam perspektif proses bisnis internal termasuk dalam kategori baik, dan kinerja RSUD Dr.Saiful Anwar Malang dalam perspektif Pembelajaran \& Pertumbuhan termasuk dalam kategori baik, sehingga dapat dikatakan bahwa RSUD Dr.Saiful Anwar Malang mampu meningkatkan kapabilitas karyawan dan komitmen karyawan.

Kata kunci: Balanced Scorecard, Pengukuran Kinerja

\section{PENDAHULUAN}

Kebijakan pemerintah yang dilakukan untuk meningkatkan pelayanan terhadap masyarakat diantaranya adalah memberi fleksibilitas dalam mengelola keuangan. Hal tersebut telah tercantum pada UU No. 1 Tahun 2014 mengenai Perbendaharaan Negara yaitu pasal 68 dan 69 yang menyebutkan bahwa instansi pemerintah yang mempunyai tugas pokok dan fungsi untuk melayani masyarakat dapat menggunakan pengelolaan keuangan yang bersifat fleksibel dengan mengutamakan produktivitasnya, efisiensinya dan efektivitasnya. Sebagai tindak lanjut dari UndangUndang tersebut, diterbitkan PP No 23 Tahun 2005 mengenai Pengelolaan Keuangan Badan Layanan Umum (BLU) serta Permendagri No 61 Tahun 2007 mengenai Aturan Mengelola Keuangan di BLUD.

Salah satu Badan Layanan Umum yang melaksanakan pelayanan kesehatan masyarakat adalah Rumah Sakit. Rumah sakit menjadi rujukan setiap masyarakat guna memperoleh pelayanan kesehatan yang layak. Hal tersebut tercantum dalam UUD 1945 pasal $28 \mathrm{H}$ ayat 1 yang menyebutkan bahwa masing-masing manusia berhak mendapatkan pelayanan kesehatan yang baik. Dalam hal ini, adanya kegiatan melayani kesehatan yang sama, memiliki mutu dan mengutamakan kepuasan pasien menjadi salah satu suatu keharusan yang dilakukan oleh pihak rumah sakit. Oleh karenanya, rumah sakit membutuhkan peran berbagai pihak guna mewujudkan tuntutan tersebut yang mencakup keuangan, SDM yang memiliki mutu dan kompeten serta fasilitas yang sesuai dengan kebutuhan.

Kinerja rumah sakit sebagai lembaga atau industri pelayanan kesehatan harus benar-benar diukur, dievaluasi, dan ditingkatkan demi menjaga kepuasan masyarakat. Hal tersebut dikarenakan rumah sakit merupakan suatu sistem dimana terjadi proses perubahan pemasukan menjadi keluaran. Masukan utamanya yaitu pasien, dokter, perawat, 
karyawan lainnya, dan sarana prasarana. Keluarannya adalah proses pelayanan jasa kesehatan (Sabarguna, 2004). Berbagai perubahan yang memungkinkan terjadi dalam lingkungan rumah sakit baik eksternal maupun internal dapat menjadi faktor penyebab pentingnya perubahan paradigma atau cara pandang bahwa rumah sakit sebagai lembaga yang bergerak dalam industri jasa tidak bisa meninggalkan aspek komersil. Oleh karenanya, dalam mengatur rumah sakit yang banyak modal, banyak karya dan banyak perkembangan teknologi didalamnya yang meliputi kegiatan mengelola pasien ketika rawat jalan, rawat inap, gawat darurat, melayani pasien dengan intensif, obat-obatan, kebutuhan akan gizi, rekam medis, pengelolaan keuangan dan lain-lain menjadi hal yang sangat krusial dan esensial.

Kebutuhan masyarakat akan pelayanan kesehatan telah bergeser dari sekedar ketersediaan ke arah kualitas. Memurut Permana (2005), masyarakat bergeser dari konsep Dumb Customer atau pelanggan yang lebih mementingkan perubahan harga menjadi Snop Customer atau pelanggan yang kurang mementingkan harga melainkan lebih mementingkan kualitas, bahkan kemudian bergeser lagi menjadi Smart Customer atau pelanggan yang berorientasi pada nilai-nilai / values. Konsep tersebut merupakan paduan seimbang antara kualitas dan harga. Fenomena tersebut dapat ditemui dalam berbagai bentuk pelayanan kesehatan, khususnya rumah sakit. Dalam beberapa waktu terakhir, rumah sakit sempat menjadi pusat perhatian publik karena banyaknya masyarakat yang merasa kecewa dengan pelayanan yang diberikan, baik dari segi kualitas, kemudahan, maupun tarif yang diterapkan.

Balanced Scorecard digunakan untuk membantu suatu organisasi untuk mengetahui bagaimana kinerja organisasi yang dihasilkan oleh karyawannya. Hal tersebut bukan hanya diukur dengan menggunakan aspek yang mengacu pada aspek keuangan saja, namun juga mengacu pada aspek lainnya yang bersifat non keuangan. Selain keseimbangan dan kesesuaian ukuran dari aspek keuangan dan non keuangan yang ditunjukkan, ternyata juga mengandung hal yang dinyatakan seimbang dan kesesuaian antara hasil pengukuran yang diterapkan di internal dan eksternal dan hasil kerja pada jangka pendek maupun kinerja yang dihasilkan dengan jangka panjang.

RSUD Dr. Saiful Anwar dapat menerapkan Balanced Scorecard sebagai alat ukurnya yang berbasis strategi, aspek yang diambil adalah financial perspective, customer perspective, internal proses business perspective, learning dan growth. Kegunaan utama penerapan Balanced Scorecard ini untuk menyimpulkan hasil kerja yang telah dilakukan oleh peagawai sebagai acuan agar pegawai dapat berkerja lebih baik lagi dan juga sebagai strategi yang akan dilakukan dikemudian hari dalam pencapaian tujuan dan perbaikan hasil kinerja.

\section{KAJIAN LITERATUR}

\section{Kinerja}

Kinerja adalah kualitas dan kuantitas karyawan di suatu tempat ia bekerja. Kinerja sendiri sama halnya dengan hasil kerja perorangan atau kelompok dalam suatu organisasi. Kinerja tidak sebatas pada karyawan yang memiliki posisi yang sangat strategis, namun juga yang berdaya guna untuk semua pegawai di suatu perusahaan tempatnya bekerja (Ilyas, 2002). Definisi lain kinerja yaitu hasil kerja yang dicapai secara perorangan atau kelompok dalam melakukan tugas yang diberikan agar sesuai dengan tujuan yang telah disepakati.

Sementara kinerja menurut Helfert (2003) merupakan suatu keadaan di dalam perusahaan dalam periode waktu tertentu. Hal tersebut merupakan suatu pencapaian perusahaan yang berpengaruh pada kegiatan dalam operasional kerja untuk memanfaatkan sumber daya yang sudah dimiliki. Kinerja adalah kata yang biasanya digunakan untuk menjelaskan sebuah tindakan yang dilakukan oleh suatu perusahaan dalam 1 kurun waktu dengan meninjau dari jumlah standar yang telah disepakati (Srimindarti, 2004).

Kinerja pemerintah bersifat multidimensional. Dalam arti, tidak ada indikator tunggal yang dapat digunakan untuk menunjukkan tingkat keberhasilan secara komprehensif untuk semua jenis instansi pemerintah. Indikator kinerja yang dipilih akan sangat tergantung pada faktor kritikal keberhasilan yang telah diidentifikasi. Mahsun (2009) menjelaskan berbagai pendekatan pengukuran kinerja organisasi sektor publik dapat diuraikan sebagai berikut:

Analisis Anggaran

Analisis anggaran adalah pengukuran kinerja yang dilakukan dengan cara membandingkan anggaran dengan realisasinya. Hasil yang diperoleh berupa selisih lebih atau selisih kurang. Teknik ini berfokus pada kinerja input yang bersifat keuangan.

- Analisis Rasio Keuangan

Pengukuran kinerja yang didasarkan atas penghitungan rasio-rasio keuangan, misalnya rasio likuiditas, rasio solvabilitas, rasio aktivitas, dan rasio pasar.

\section{- Balanced Scorecard Method}

Balanced Scorecard adalah sebuah sistem manajemen untuk mengimplementasikan strategi, mengukur kinerja yang tidak 
hanya dari sisi finansial semata melainkan juga melibatkan sisi non finansial, serta untuk mengkomunikasikan visi, strategi, dan kinerja yang diharapkan.

- Performance Audit (Pengukuran Value for Money)

Pengukuran dan pemeriksaan kinerja dengan berdasarkan pada ukuran ekonomi, efisiensi, dan efektivitas.

\section{Balanced Scorecard}

Menurut Kaplan dan Norton (2013:241)

Balanced Scorecard adalah sebuah sistem manajemen untuk mengimplementasikan strategi, mengukur kinerja yang tidak hanya dari sisi finansial semata melainkan juga melibatkan sisi non finansial, serta untuk mengkomunikasikan visi, strategi, dan kinerja yang diharapkan.

Berdasarkan konsep Balanced Scorecard (BSC), kinerja keuangan sebenarnya merupakan hasil atau akibat dari kinerja non keuangan (pelanggan, proses bisnis internal, serta pembelajaran dan pertumbuhan). Pada awal implementasi Balanced Scorecard perusahaan yang ikut serta dalam eksperimen tersebut memperlihatkan pelipatgandaan kinerja keuangan mereka. Keberhasilan ini didasari sebagai akibat dari penggunaan ukuran kinerja Balanced Scorecard yang komprehensif. Dengan menambah ukuran kinerja non keuangan, eksekutif dipacu untuk memperlihatkan dan melaksanakan usahausaha yang merupakan pemacu sesungguhnya (the real driver) untuk mewujudkan kinerja keuangan. Itulah sebabnya mengapa Balanced Scorecard disebut "Measure That Driver Performance".

Balanced Scorecard sendiri merupakan suatu alat pengukuran kinerja perusahaan yang mengukur kinerja perusahaan secara keseluruhan baik keuangan maupun non keuangan dengan mempertimbangkan empat aspek yang berkaitan dengan perusahaan, antara lain: aspek keuangan, pelanggan, proses bisnis internal, dan pembelajaran dan pertumbuhan (Blocher). Konsep BSC berkembang sejalan dengan implementasi konsep tersebut. BSC terdiri dari dua kata: (1) kartu skor (Scorecard) dan (2) berimbang (Balanced). Kartu skor adalah kartu yang digunakan untuk mencatat skor hasil kinerja seseorang. Kartu skor juga dapat digunakan untuk merencanakan skor yang hendak diwujudkan oleh personel masa depan. Melalui kartu skor, skor yang hendak diwujudkan personel di masa depan dibandingkan dengan hasil kinerja sesungguhnya.

Langkah-langkah Balanced Scorecard meliputi empat proses manajemen baru.
Pendekatan ini mengkombinasikan antara tujuan strategi jangka panjang dengan peristiwa jangka pendek. Keempat proses tersebut menurut (Kaplan dan Norton, 2013) adalah :

a. Menterjemahkan visi, misi dan strategi perusahaan

Untuk menentukan ukuran kinerja, visi organisasi dijabarkan dalam tujuan dan sasaran. Visi adalah gambaran kondisi yang akan diwujudkan oleh perusahaan di masa datang. Tujuan juga menjadi salah satu landasan bagi perumusan strategi untuk mewujudkannya. Dalam proses perencanaan strategik, tujuan ini kemudian dijabarkan dalam sasaran strategik dengan ukuran pencapaiannya.

b. Mengkomunikasikan dan mengaitkan berbagai tujuan dan ukuran strategis Balanced Scorecard

Dapat dilakukan dengan cara memperlihatkan kepada tiap karyawan apa yang dilakukan perusahaan untuk mencapai apa yang menjadi keinginan para pemegang saham dan konsumen. Hal ini bertujuan untuk mencapai kinerja karyawan yang baik.

c. Merencanakan, menetapkan sasaran, menyelaraskan berbagai inisiatif rencana bisnis

Memungkinkan organisasi mengintegrasikan antara rencana bisnis dan rencana keuangan mereka.

Balanced scrorecard sebagai dasar untuk mengalokasikan sumber daya dan mengatur mana yang lebih penting untuk diprioritaskan, akan menggerakkan kearah tujuan jangka panjang perusahaan secara menyeluruh.

d. Meningkatkan umpan balik dan pembelajaran strategis

Proses keempat ini akan memberikan strategis learning kepada perusahaan. Dengan Balanced Scorecard sebagai pusat sistem perusahaan, maka perusahaan melakukan monitoring terhadap apa yang telah dihasilkan perusahaan dalam jangka pendek.

Penerapan BSC mengalami perkembangan yang cukup pesat di dunia bisnis, hal tersebut juga terjadi pada sektor publik di negara Amerika Serikat yang kemudian menyebar kepenjuru negara salah satunya adalah Indonesia (Sutanto, 2009). Penerapan BSC yang diterapkan juga harus berjalan sesuai dengan hukum dan prosedur yang berlaku, beberapa Peraturan Pemerintah dalam mengatur BSC, dapat ditinjau dari :

a. Peraturan pertama yaitu diatur dalam Instruksi Presiden Nomor 7 Tahun 1999 
yaitu tentang kewajiban instansi pemerintah membuat LAKIP

b. Peraturan kedua, yaitu diatur dalam Peraturan Menteri Negara Pemberdayaan Aparatur Negara, No.PER/09/M.PAN/5/2007 tentang Pedoman Umum Penetapan Indikator Kinerja Utama (IKU) di Lingkungan Instansi Pemerintah.

c. Peraturan ketiga, diatur dalam Peraturan Menteri Negara Pemberdayaan Aparatur Negara, No.PER/11/M.PAN/08/2007 tentang Penetapan Indikator Kinerja Utama (IKU) di Lingkungan Kementrian Negara Pemberdayaan Aparatur Negara

Dalam melakukan penerapan BSC dapat dilakukan dengan langkah atau tahap yang bermacam-macam yaitu berdasarkan "Association Balanced Scorecard" oleh The Balanced Scorecard Institute (Sutanto, 2009) yang dapat dilakukan dengan beberapa komponen seperti :

a. Peta Strategi (berdasarkan hubungan kausal empat perspektif)

b. Sasaran Strategi ( Strategic Objectives)

c. Pengukuran Kinerja

d. Penetapan target

e. Penetapan Rencana Kinerja (Initiative)

f. Perumusan Visi dan Misi

g. Ukuran (Measurement)

\section{METODE PENELITIAN}

Penelitian ini menggunakan pendekatan mixed methods. Adapun dalam melakukan penelitian menggunakan langkah penelitian dengan mengkombinasikan dua pendekatan yaitu pendekatan kualitatif dan pendekatan kuantitatif. Creswell (2010: 5) memberikan pengertian bahwa yang dimaksud dengan mixed methods adalah pendekatan penelitian yang menggunakan dua pendekatan secara bersamaan yaitu antara kualitatif dan kuantitatif. Sedangkan Sugiyono (2011: 404) mendefinisikan mixed methods merupakan suatu metode penelitian yang menggunakan atau menggabungkan anatara metode kuantitatif dan kualitatif yang dapat dipergunakan secara bersamasama dalam satu penelitian, hal tersebut dengan tujuan bahwa data yang akan diperoleh dan dianalisis adalah data yang valid, komprehensif, reliabel dan obyektif yang dibutuhkan dalam penelitian.

Arikunto (2012) memberikan penjelasan bahwa dalam melakukan kegiatan penelitian, peneliti membutuhkan sebuah alat dalam pengumpulan data yang dapat diperoleh melalui tanya menjawab pertanyaan riset (metode survei) atau metode observasi. Data primer di dapat dari sumber informan yaitu individu atau perseorangan seperti hasil wawancara yang dilakukan oleh peneliti. Adapun yang termasuk dalam data primer diantaranya adalah hasil wawancara berkaitan dengan permasalahan rumah sakit, dan hasil wawancara dengan kinerja rumah sakit. Adapun data primer merupakan data yang dipergunakan untuk mendukung informasi atau data primer diperoleh oleh peneliti yaitu dari bahan pustaka, literatur, penelitian terdahulu, buku, dan lain sebagainya. Salah satu data sekunder misalnya dokumen seperti: Struktur Organisasi, Profil Rumah Sakit, Laporan Keuangan, Laporan Tahunan, serta data pendukung lainnya.

Pengumpulan data dilakukan dengan menggunakan wawancara dan observasi. Adapun kegiatan wawancara yang dilakukan oleh peneliti untuk menguatkan atas hasil pengolahan data yang memiliki kecenderungan jawaban yang tidak memuaskan atau jawaban yang tidak disetujui. Selanjutnya, pada teknik pengumpulan data, peneliti menggunakan observasi non partisipan yang artinya peneliti tidak terlibat langsung dengan aktivitas orang-orang yang sedang diamati tetapi hanya sebagai pengamat independen.

\section{HASIL PENELITIAN \\ Penentuan Bobot Balanced Scorecard}

Tujuan dari pemberian bobot adalah untuk melakukan penilaian hasil yang akan diukur, menurut Mulyadi (2011:347) pemberian bobot disesuaikan dengan visi, misi dan tujuan dari perusahaan dan total keempat perspektif harus $100 \%$.

Bobot yang ditetapkan di RSUD Dr. Saiful Anwar Kota Malang adalah sebagai berikut:

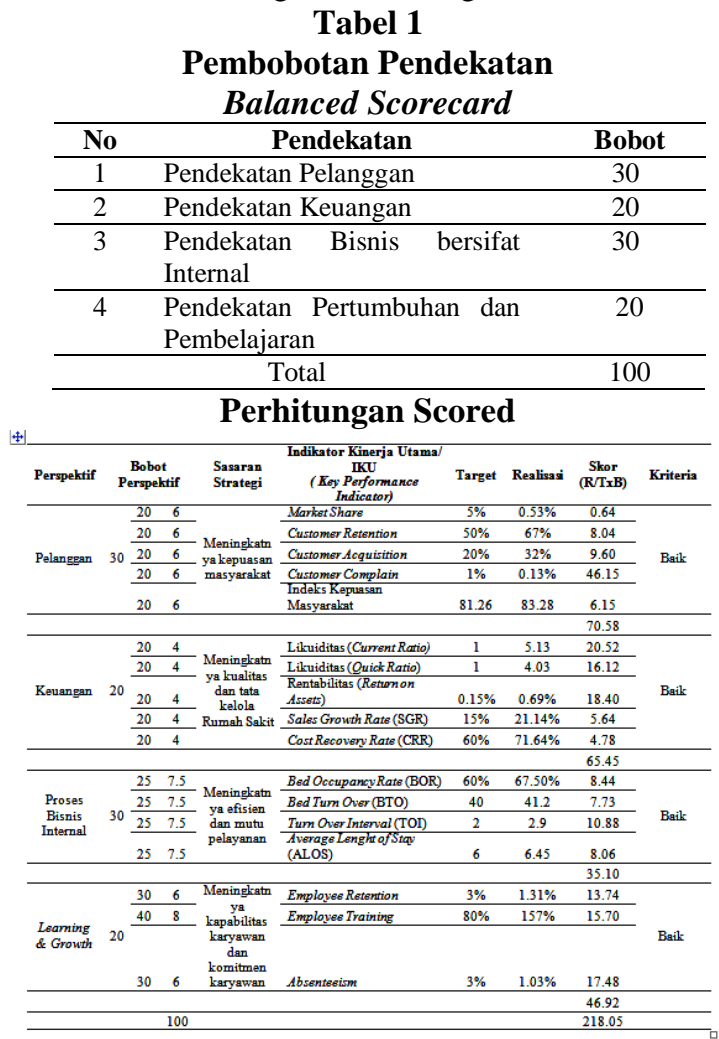




\section{PEMBAHASAN}

Berdasarkan hasil perhitungan Scorecard RSUD Dr.Saiful Anwar Malang tahun 2014 - 2016 yang terbagi dalam 4 perspektif yaitu perspektif pelanggan, perspektif keuangan, perspektif dengan proses bisnis berbasis internal serta learning \& growth secara keseluruhan termasuk dalam kinerja baik.

Pertama, perspektif pelanggan. Dalam melakukan pengukuran kinerja melalui manajemen pada prespektif pelanggan diukur menggunakan tingkat kepuasan masyarakat atau pasien dengan menggunakan lima indikator yaitu : Market Share, Customer Retention, Customer Acquisition, Customer Complain dan Indeks Kepuasan Masyarakat.

Strategi yang dapat dilakukan RSUD Dr. Saiful Anwar guna meningkatkan perspektif pelanggan diantaranya dengan memanfaatkan media sebagai alternatif berbagi informasi tentang segala sesuatu yang berhubungan dengan rumah sakit dan lebih aktif dalam berbagai kegiatan sosial. Hal tersebut dikarenakan, hasil pengukuran Balanced Scorecard dalam perspektif pelanggan RSUD Dr. Saiful Anwar yang belum mencapai target maksimal adalah Market Share. Menurut Kaplan dan Norton (2013:24), Market Share mencerminkan bagian yang dikuasai perusahaan atas keseluruhan pasar yang ada, yang meliputi antara lain: jumlah pelanggan, jumlah penjualan, dan volume unit penjualan.

Adanya media dan kegiatan sebagai sarana komunikasi diharapkan dapat membantu rumah sakit dalam menyampaikan pesan tentang rumah sakit kepada masyarakat. Menurut Kaplan dan Norton (2013:241), menjaga komunikasi dan hubungan menjadi hal penting guna tercapainya kinerja yang baik. Komunikasi dan hubungan dapat membantu perusahaan untuk mencapai keinginan para pemegang saham ataupun konsumen. Ketika masyarakat sudah menerima kehadiran rumah sakit tentunya akan terjalin suatu hubungan yang baik antara konsumen dengan perusahaan, karena rumah sakit mampu memberikan sarana komunikasi dengan baik kepada masyarakat baik berupa media ataupun kegiatan. Dalam hal ini, diharapkan RSUD Dr. Saiful Anwar mampu menguasai pasar dengan jangkauan lebih luas karena keberadaannya yang diterima oleh masyarakat.

Kedua, perspektif keuangan. Dalam melakukan pengukuran kinerja pada perspektif keuangan dapat dilihat dari peningkatan kualitas dan pengelolaan rumah sakit melalui 5 (lima) indikator yaitu : Likuiditas (Current Ratio), Likuiditas (Quick Ratio), Rentabilitas (Return on Asset), Sales Growth Rate (SGR), dan Cost Recovery Rate (CRR).

Strategi lanjutan yang dapat digunakan RSUD Dr.Saiful Anwar dalam perspektif keuangan diantaranya rumah sakit dapat meninjau ulang bagaimana implementasi dan pelaksanaan strategi yang dilakukan selama ini. Apakah strategi tersebut sudah efektif atau belum untuk diterapkan lebih lanjut. Strategi yang efektif seharusnya sudah mampu mencapai tujuan yang ditetapkan, sehingga perusahaan tidak harus melakukan investasi lebih jauh kecuali hanya untuk memelihara dan perbaikan fasilitas, tidak untuk melakukan ekspansi atau membangun suatu kemampuan baru. Hal ini sebagaimana Kaplan dan Norton (2013) yang menjelaskan tahap tertinggi dalam sebuah bisnis adalah harvest atau panen.

Tahap harvest merupakan tahap kematangan (mature). Artinya, suatu tahap dimana perusahaan melakukan panen (harvest) terhadap investasi mereka. Tujuan utama dalam tahap ini adalah memaksimumkan arus kas yang masuk ke perusahaan. Sasaran keuangan untuk harvest adalah cash flow maksimum yang mampu dikembalikan dari investasi dimasa lalu dan penghematan sebagai kebutuhan modal kerja. Oleh karenanya, rumah sakit yang sudah mampu mencapai tahap ini tentunya akan mempunyai kestabilan keuangan yang lebih baik, sehingga kinerja rumah sakit dalam perspektif keuangan dapat tercapai dengan maksimal.

Ketiga, perspektif Proses Bisnis Internal. Dalam melakukan pengukuran kinerja pada perspektif proses bisnis berbasis internal diukur dengan menggunakan peningkatan efisien dan mutu pelayanan melalui 4 aspek yaitu Bed Occupancy Rate (BOR), Bed Turn Over (BTO), Turn Oner Interval (TOI), Average Lenght of Stay (ALOS).

Salah satu upaya yang dapat dilakukan RSUD Dr. Saiful Anwar Malang dalam menjaga tingkat persepktif bisnis internal diantaranya dengan melakukan inovasi. Inovasi menjadi hal penting bagi perusahaan karena dalam proses bisnis internal terdapat nilai-nilai yang diinginkan konsumen dan dapat memberikan pengembalian yang diharapkan oleh para pemegang saham. Inovasi yang dilakukan dalam perusahaan biasanya dilakukan oleh bagian riset dan pengembangan. Dalam tahap inovasi ini tolok ukur yang digunakan adalah besarnya produk-produk baru, lama waktu yang dibutuhkan untuk mengembangkan suatu produk secara relatif jika dibandingkan perusahaan pesaing, besarnya biaya, banyaknya produk baru yang berhasil dikembangkan (Kaplan dan Norton, 2013: 83). Oleh karenanya, inovasi merupakan satu strategi yang menjadi keharusan untuk dilakukan perusahaan agar proses bisnis internal dapat terjaga dengan baik.

Keempat, perspektif Learning \& Growth. Dalam melakukan pengukuran kinerja pada perspektif Learning \& Growth diukur dengan meningkatnya kapabilitas karyawan dan komitmen karyawan yang diukur melalui 3 (tiga) indikator, 
yaitu Employee Retention, Employee Training dan Absenteeism.

Strategi yang bisa dilakukan RSUD Dr. Saiful Anwar Malang agar kinerja dari perspektif Learning \& Growth tetap baik diantaranya adalah dengan memperhatikan kepuasan karyawan. Karyawan yang puas dengan perusahaan tentunya akan lebih produktif dalam bekerja. Sebaliknya karyawan yang tidak merasa puas dengan perusahaan juga akan menurunkan produktivitas kerjanya. Ketika karyawan sudah tidak produktif, tentunya akan berpengaruh pada perusahaan, karena tugas dan tanggung jawabnya tidak dapat dilaksanakan dengan maksimal. Menurut Kaplan dan Norton, (2013:25) produktivitas kerja merupakan hasil dari pengaruh agregat peningkatan keahlian moral, inovasi, perbaikan proses internal dan tingkat kepuasan konsumen. Oleh karenanya, kepuasan karyawan harus menjadi perhatian khusus bagi perusahan jika ingin terus berjalan dan berkembang ke arah yang lebih baik.

Selain kepuasan karyawan, hal yang harus diperhatikan perusahaan agar mampu memenuhi perspektif Learning \& Growth adalah sistem informasi. Menurut Kaplan dan Norton, (2013: 25) sistem informasi yang digunakan dapat menunjang kinerja. Organisasi atau perusahaan dalam menjalankan usahanya harulah memiliki sistem informasi yang baik. Sistem informasi yang baik misalnya dengan memiliki sebuah prosedur yang terarah yang kemudian akan membantu orang dalam memahami prosedur yang kemudian akan memberikan dampak pada kemudahan dalam menjalankannya. Adapun kriteria dalam mengukur apakah informasi yang dibutuhkan mudah didapatkan, tepat dan tidak memerlukan waktu lama untuk mendapat informasi tersebut. Oleh karenanya, rumah sakit harus memperhatikan sistem informasi yang digunakan guna memenuhi perspektif Learning \& Growth. Berdasarkan hasil matrik Balance Scorcard dari empat prespektif dapat diketahui bahwa keseluruhan memiliki memiliki skor 218,05 dan di atas 100 sehingga memiliki kategori baik atau tercapai.

\section{PENUTUP}

\section{A. Kesimpulan}

Pengukuran kinerja sektor publik berbasis metode Balanced Scorecard RSUD Dr.Saiful Anwar Malang tahun 2014 - 2016 yang terbagi dalam 4 perspektif yaitu perspektif pelanggan, perspektif keuangan, perspektif dengan proses bisnis berbasis internal serta learning \& growth secara keseluruhan termasuk dalam kinerja baik.

Kinerja RSUD Dr.Saiful Anwar Malang dalam perspektif pelanggan termasuk dalam kategori sangat baik dengan nilai mencapai 83,28. Hal tersebut menunjukkan bahwa secara kumulatif masyarakat menilai pelayanan yang diberikan
RSUD Dr.Saiful Anwar Malang sudah sesuai dengan harapan dan kebutuhan mereka, meski indikator market share belum bisa tercapai dengan maksimal.

Kinerja RSUD Dr.Saiful Anwar Malang dalam perspektif keuangan termasuk dalam kategori baik. Artinya, RSUD Dr.Saiful Anwar Malang mampu menutup biaya (cost) atau membayar biaya hutang daripada harus menerima retribusi dari pasien (revenue), meski sempat mengalami penurunan yang disebabkan pendapatan yang menurun.

Kinerja RSUD Dr.Saiful Anwar Malang dalam perspektif proses bisnis internal termasuk dalam kategori baik, sehingga dapat dikatakan bahwa RSUD Dr.Saiful Anwar Malang mampu meningkatkan efisiensi dan mutu pelayanan. Hal tersebut ditunjukkan dengan tercapainya semua indikator perspektif bisnis internal yang terdiri dari 4 komponen, yaitu Bed Occupancy Rate (BOR), Bed Turn Over (BTO), Turn Oner Interval (TOI), Average Lenght of Stay (ALOS).

Kinerja RSUD Dr.Saiful Anwar Malang dalam perspektif Learning \& Growth termasuk dalam kategori baik, sehingga dapat dikatakan bahwa RSUD Dr.Saiful Anwar Malang mampu meningkatkan kapabilitas karyawan dan komitmen karyawan. Hal tersebut juga ditunjukkan dengan tercapainya semua indikator dalam perspektif Learning \& Growth yang terdiri dari 3 (tiga) indikator, yaitu Employee Retention, Employee Training dan Absenteeism.

\section{B. Saran}

1. Melakukan evaluasi dan pemantauan yang konsisten dan berkesinambungan, baik dalam jangka pendek seperti halnya pemantauan terhadap pelaksanaan program kerja, maupun jangka panjang yang mengarah terhadap pengaruh perubahan lingkungan pada visi, misi dan strategi yang digunakan rumah sakit.

2. Dalam penerapan Balanced Scorecard sebaiknya didukung oleh semua personel yang ada dan koordinasi yang baik sehingga Balanced Scorecard benar-benar dapat diterapkan. Empat perspektif dalam Balanced Scorecard akan dapat memperbaiki bahkan dapat pula menambahkan komponenkomponen penting yang harus diperhatikan oleh pihak RSUD Dr. Saiful Anwar Malang untuk meningkatkan kinerjanya.

\section{DAFTAR PUSTAKA}

Arikunto, Suharsimi, 2012. Prosedur Penelitian Suatu Pendekatan Praktik. Rineka Cipta. Jakarta.

Gaspersz, Vincent. 2005. Sistem Manajemen Kinerja Terintegrasi Balanced Scorecard 
Dengan Six Sigma Untuk Organisasi Bisnis dan Pemeritah. Gramedia Pustaka Utama. Jakarta.

Hafizurrachman HM, dkk. 2009. Kebijakan Keperawatan Berbasis Kinerja di RSU Tangerang. Jurnal Manajemen Pelayanan Kesehatan. Vol 15, No 1, p.12-19.

Ilyas, Yasli. 2002. Kinerja: Teori, Penilaiain dan Penelitian. Pusat Kajian Ekonomi Kesehatan Fakultas Kesehatan Masyarakat Universitas Indonesia, Depok Jakarta.

Kaplan, Robert, S., \& Norton, David,P.2013. The Balanced Scorecard: Translating Strategy Into Action. Harvard Business School Press. Massachusetts.

Mahmudi. 2005. Manajemen Kinerja Sektor Publik. Akademi Manajemen Perusahaan YKPN.
Mahmudi. 2007. Manajemen Kinerja Sektor Publik. YKPN.Yogyakarta.

Mahsun, Mohamad, 2009. Pengukuran Kinerja Sektor Publik. BPFE.Yogyakarta.

Permana, H.S. 2005. Kepemimpinan dalam Manajemen Rumah Sakit. Andi Offset. Yogyakarta.

Sabarguna, B. S. 2004. Quality Assurance Pelayanan Rumah Sakit. Edisi Kedua. Konsorsium Rumah Sakit Islam Jateng DIY. Yogyakarta

Srimindarti, Ceacilia. 2004. Balanced Scorecard Sebagai Alternatif untuk Mengukur Kinerja. Fokus Ekonomi. Vol. 3, No. 1, April.

Sugiyono. 2012. Metode Penelitian Kuantitatif Kualitatif dan $R \& D$. Alfabeta. Bandung.

Sugiyono.2006. Metode Penelitian Kuantitatif, Kualitatif dan $R$ \&. D. Alfabeta. Bandung. 